\title{
Customers' impulse buying in social commerce: The role of flow experience in personalized advertising
}

\author{
Lia Febria Lina \\ Universitas Teknokrat Indonesia, Lampung, 35111, Indonesia \\ liafebrialina@teknokrat.ac.id \\ Larasati Ahluwalia* \\ Universitas Teknokrat Indonesia, Lampung, 35111, Indonesia \\ larasati.ahluwalia@teknokrat.ac.id \\ *Penulis Korespondensi
}

Submitted: Jul 26, 2021; Reviewed: Aug 20, 2021; Accepted: Sep 14, 2021

\begin{abstract}
One of the advantages of using social commerce, especially Instagram, is the display of paid advertisement that are in accordance with consumer preferences or also called personalization. Previous study on the effectiveness of personalized advertising still shows mix result both positive and negative. Based on the limitations of previous research, the focus of this research is to examine and analyze the influence of personalized advertising on the value of advertising which then affects impulse purchases in social commerce and flow experience as moderation. This study using survey method on 157 active Instagram user. The findings in this result show that personalized advertising have positif affect to advertising value and encourage impulse buying. Then flow experience found strengthen effect advertising value on impulse buying. The result indicates when user has fully involved, happy, and excitement when using social media, then receive personalize advertising that match with their preference will encourage impulse buying.
\end{abstract}

Keywords: flow experience; impulse buying; personalized advertising

\begin{abstract}
Abstrak: Salah satu keuntungan menggunakan social commerce khususnya Instagram adalah tampilan iklan berbayar yang sesuai dengan preferensi konsumen atau umumnya disebut sebagai personalisasi. Penelitian terkait personalisasi iklan masih menunjukkan hasil yang berbeda-beda baik positif dan negatif. Penelitian ini bertujuan untuk mengisi gap sebelumnya dengan menguji dan menganalisis pengaruh personalisasi iklan pada nilai iklan yang kemudian memengaruhi impulse buying dalam social commerce dan flow experience sebagai variabel moderasi. Penelitian ini menggunakan metode survei terhadap 157 orang pengguna aktif Instagram. Temuan dalam penelitian ini menunjukkan bahwa iklan yang dipersonalisasi memiliki pengaruh positif terhadap nilai iklan dan mendorong pembelian impulsif. Kemudian flow experience memperkuat pengaruh nilai iklan pada impulse buying. Hasil penelitian menunjukkan ketika pengguna telah sepenuhnya terlibat, senang, dan gembira saat menggunakan media sosial, kemudian menerima iklan yang dipersonalisasi sesuai dengan preferensi mereka dapat mendorong pembelian impulsif.
\end{abstract}

Kata kunci: flow experience; impulse buying; personalisasi iklan 


\section{INTRODUCTION}

In the development of the internet world encourages changes in various aspects ranging from social, economic, and politic. Since the beginning of its existence, the internet has made it very easy in various ways, one of which is interaction in social networks. Currently, there are many type of popular social network sites such as Linked In, Instagram, Facebook, and Twitter creating new business model opportunities that also encourage electronic sales transactions which are also known as social commerce (Liang \& Turban, 2011). Currently, the development of social commerce is increasing every year.

One of the advantages of using social commerce, especially Instagram, is the display of paid advertisements that are in accordance with consumer preferences or also called personalization. Personalized advertising or what is known as OPA (Online Personalized Advertising) is a type of advertisement that is served on advertising media that has been tailored to users based on browsing activity, their previous purchases, personal information such as username, purchase history, psychographic aspects, user current location, and lifestyle user (Baek \& Morimoto, 2012; Chen et al., 2019). Along with the development of big data, personalization is also growing and has been trusted by various marketers. However, previous study on the effectiveness of advertising personalization still shows mixed results both positive and negative consequences (Bang et al., 2019). Several research provide positive results on perceptions and behavior (De Keyzer et al., 2015; Dehghani et al., 2016; Lee et al., 2017; Van Reijmersdal et al., 2017; Shanahan et al., 2019, Lina \& Setiyanto, 2021). Other research show contradictory result, personalized advertising does not have effect on advertising value and encourage intrusiveness (Kim \& Han, 2014; Van Doorn \& Hoekstra, 2013). Instagram is one of the social commerce that marketers use in serving personalized advertising. Instagram also has the advantage of making it easier to direct customers to other websites or visits to stores to further drive online purchases. So it is very possible that personalized advertising on social media has important role in encouraging online impulse buying (Dodoo \& Wu, 2019). In addition Chen et al. (2019) also suggested that it is necessary to conduct research on impulse buying in the context of personalized advertising.

Impulse buying is an area that has been widely discussed in recent years. This is also supported by the rapid development of the platform which causes internet-based accidental purchases to have also emerged in the discussion (Liyanage \& Wijesundara, 2020). Impulse buying can be considered as unintentional purchases, furthermore, impulse purchases also go beyond unintentional purchases because they make customers really need emotionally before buying a product (Liyanage \& Wijesundara, 2020). Online impulse buying has attracted the attention of researchers in various fields, especially in social commerce field which is still relatively new (Abdelsalam et al., 2020). Iyer et al. (2020) doing a meta-analysis on 231 articles using a sample of more than 75,000 consumers about the relationship between impulse buying, both internal and external factors. The research outlines the driving factors consisting of traits (example: sensation seeking, impulse buying tendencies and self identitiy), motivation (example: utilitarian, hedonic and norm), consumer resources (example: time, money, age, and gender), and marketing stimuli that will encourage users to make impulse purchases. In addition, mediating and moderating factors are also discussed, such as self-control and consumer mood. In various existing studies, inconsistent results were also obtained, due to differences in context and various determinants. Hedonic, utilitarian, sensation seeking, variety seeking, and novelty seeking (Park et al., 2012; Olsen et al., 2016), direct promotion, online media promotion (Anggarini \& Permatasari., 2020), and age have positive affect to impulse buying (Thompson \& Prendergast, 2015; Verplanken \& Herabadi, 2001). Then, Dodoo \& Wu (2019) also find advertising value did not have positif affect on impulse buying, the rating or advertising process leads to slow decision making. This research encourages further research to re-examine to get a more complete explanation.

So, this study tries to use the flow experience moderating variable. The convenience felt by users when using mobile phones and browsing Instagram encourages users to shop online. Research on flow experience in Instagram is considered important in addition to more and more marketers who use the platform to reach a larger audience (Shahpasandi et al., 2020). The focus of this research is to examine and analyze the influence of personal advertising on the value of advertising which then affects impulse purchases in social commerce and flow experience as moderation. 
Liang \& Turban (2011) defined social commerce as to the bold delivery of buying and selling activities and transactions on social media and is considered as part of e-commerce which involves the use of social media to support e-commerce transactions and activities, support social interaction and user content contribution. Social commerce reffered to as internet-based commercial application, utilizing social media and Web 2.0 technology that supports social interaction and user-generated content to assist consumers in making decisions in purchasing products or services both online markets and communities (Huang \& Benyoucef, 2013). Basically, social commerce is an application that has the main function to promote the social interaction of its users (Zhang et al., 2020). So, it can be said that social commerce is a combination of social activities and commercial.

Personalized advertising or what is known as OPA (Online Personalized Advertising) is a type of advertisement displayed on advertising media that has been tailored to users based on their activity, past purchases, personal information such as user name, purchase history, psychographic aspects, location, and user lifestyle (Baek \& Morimoto, 2012; Chen et al., 2019)

There are various studies that have explored the value of advertising as the extent to which attitude change is influenced by the level of interest and how a person adopts information (Lee et al., 2017) However, advertising value model, it is more about the advertising appraisal process itself than differences in cognitive processes (Dodoo \& Wu, 2019; Baek \& Morimoto, 2012; Kim \& Han, 2014). So that the concept of advertising value is currently referred to as an evaluation of the level of influence of advertising-on-advertising attitudes. Current advertising value research focuses on how factors such as demographic characteristics, advertising influence, and cultural differences. There are antecedents that affect advertising value, which can be summarized as information, entertainment, distraction, and personalization (Lee et al., 2017).

Impulse buying is an unplanned purchase, which occurs when a person receives a certain stimulus. This also applies to new purchases that are different from the usual buying pattern (Abdelsalam et al., 2020). Rook \& Fisher (1995) state that impulse buying is the tendency of consumers to buy spontaneously, in a hurry, and not reflectively. When consumers shop impulsively, they do not have a detiled shopping list, thus enabling them to accept sudden purchase ideas (Rook \& Fisher, 1995). Impulse buying behavior is more common in online shopping, because of the many conveniences in online shopping such as flexibility, ease of transactions, variety of similar products offered, competitive prices, product personalization (Dawson \& Kim, 2010; Grandon \& Pearson, 2004; Srinivasan et al., 2002). Impulse buying is very important for marketers because it can attract new customers, increase sales, and maintain customer relationships (Sun \& Wu, 2011). However, behind all the benefits of impulse buying, when consumers are dissatisfied with the results of an impulse purchase, they will give an unfavorable rating in online stores, which on e-WOM is negative. Therefore, impulsive buying behavior is necessary to understand better marketing strategies.

OPA is a type of advertisement that is served on advertising media that has been tailored to users based on their browsing activity, previous purchases, personal information such as username, purchase history, psychographic aspects, location, and user lifestyle (Baek \& Morimoto, 2012; Chen et al., 2019). So that consumers who receive personalized advertisements feel that advertisements are relevant to themselves and are made for each consumer, because the advertisements received by one consumer will be different from other consumers due to differences in preferences. When advertising is in accordance with consumer preferences, personalization is expected to be able to make users feel that advertising is useful and valuable to consumers because advertising information is created based on user preferences, needs, interests, and browsing history. In previous studies in different contexts the relationship of advertising personalization on advertising value has been tested, which states that advertising personalization has a positive effect on advertising value (Lee et al., 2017). So that the following hypothesis is formed:

H1: Personalized advertising has a positive effect on adversiting value.

Consumer attitudes and behavior towards an object are influenced by the feeling of liking or disliking when seeing an object (Zhang \& Mao, 2016). According to Dodoo \& Wu (2019), users tend to engage in impulse buying when they feel that advertisements in social media are useful so that user will encourage to buy products or pay for services that are considered valuable at the time the advertisements are shown. So, when someone receives an advertisement that is considered valuable and useful, they will be motivated to make a decision. So that the hypothesis is formed as follows: 
$\mathrm{H} 2$ : Advertising value has a positive effect on impulse buying.

Flow defined to the fully immersed state that users experience when they act with total involvement. Users come to be absorbed in their activity in the flow state and the focus is narrowed to their activity (Kim \& Han, 2014). When Instagram creates memorable ads, good content, and facilitates consumer navigation, it can increase flow and ultimately lead consumers to make impulse buying. The more users feel it is easier and see the personalization of advertising as interesting content, the more they can be encouraged to make impulse buying. This is supported by research conducted by Shahpasandi et al. (2020) and Kim \& Han (2014) which states that flow experience has an effect on impulse buying and purchase intention. So that the hypothesis is formed as follows:

H3: Flow experience strengthen advertising value on impulse buying.

\section{METHOD}

The purpose of this study was to examine and analyze the effect of personalize advertising on advertising value, then affect impulse buying. This study also examine flow experience as moderating variable, will strength effect advertising value on impulse buying. In order to achieve this goal, this study uses quantitative method by distributing questionnaires via Google Form to Instagram users. The questionnaire contains statements related to personalized advertising variables modified from Xu et al. (2008) and Ünal et al. (2011), advertising value modified from Ducoffe (1995) and Liu et al. (2012), impulse buying modified from Sun \& Wu (2011), and flow experience modified from Novak et al. (2003) and Chang (2013) using a Likert scale of 1 (strongly disagree) to 5 (strongly agree). The population in this study are users of the Instagram application in Indonesia, with a purposive sample selection technique. The criteria for this research sample are internet active user and received advertisement marked "sponsored". After getting the data from the required sample, this research processes the data using the WarpPLS 7.0 application. The analytical method used is validity and reliability testing, as well as hypothesis testing using the Structural Equation Model method to meet research needs.

\section{RESULTS AND DISCUSSION}

\subsection{Observation results}

This study uses a sample of 156 respondents who are active users of Instagram and know about advertising personalization. Respondents on average spent 1-3 hours using Instagram as much as $68.6 \%$ and $4-5$ hours $17.3 \%$ and $>5$ hours $14.5 \%$. With the majority of respondents aged $17-25$ as much as $72,4 \%$. With the majority of female respondents amounting to $76.2 \%$ while only $23.8 \%$ of male respondents. Before testing the hypothesis, this study tested the fit model as well as the validity and reliability of the research instrument. This study has a GOF value of 0.539 , which means the model is appropriate and can be tested further. The results of testing the validity and reliability in this study are seen from the AVE and Cronbach Alpha values which have met the criteria, namely $>0.5$, can be seen in Table 1 so that the instrument is said to be valid and reliable and can be tested for hypotheses.

Table 1 . Validity and reliability test result

\begin{tabular}{lcccc}
\hline & PI & AV & IB & FE \\
\hline Composite reliability & 0.911 & 0.915 & 0.900 & 0.882 \\
Cronbach alpha & 0.882 & 0.861 & 0.870 & 0.821 \\
AVE & 0.634 & 0.783 & 0.564 & 0.652 \\
\hline
\end{tabular}

Source: Test result from PLS 7.0 (2021)

PI: Personalized Advertising; AV: Advertising Value; IB: Impulsive Buying; FE: Flow Experience 


\subsection{Result and discussion}

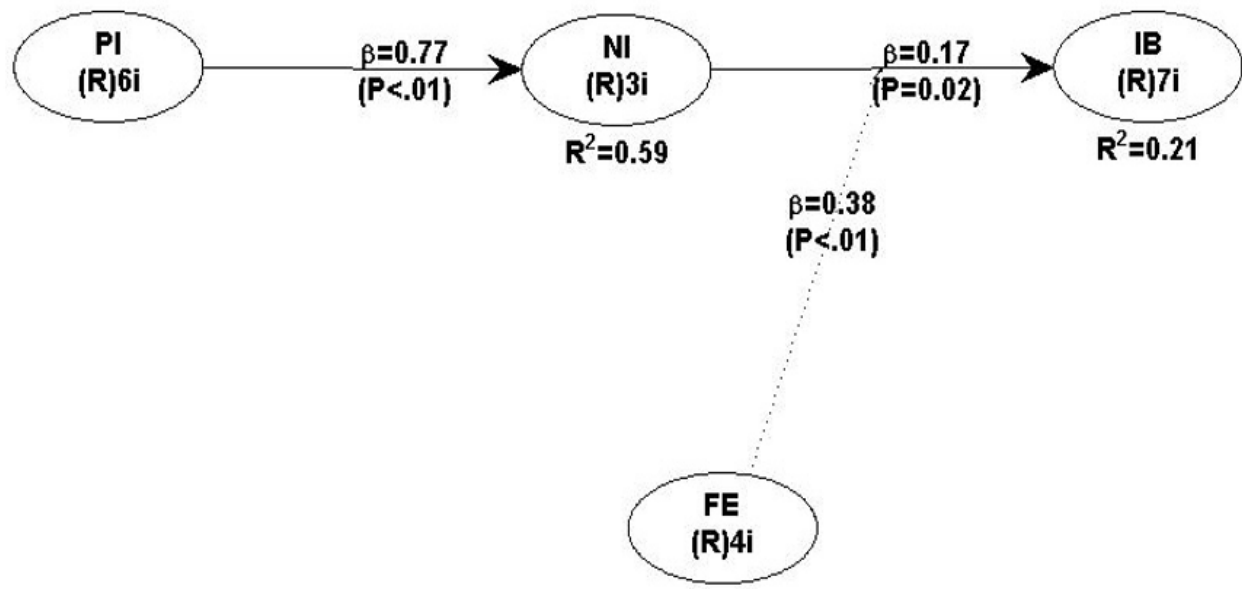

Figure 1. Result of hypothesis testing

Source: Test result from PLS 7.0 (2021)

Testing hypothesis 1 has a $\mathrm{P}$-value $<.01$ with $\beta$ value of 0.77 , meaning that personalized advertising has a positive effect on advertising value (supported hypothesis). When ads are tailored to consumers' needs, interests, and browsing history, users find the ads useful and valuable. This study is in line with research conducted by Lee et al. (2017). Furthermore, testing hypothesis 2 has a P-value of 0.02 with $\beta$ value of 0.17 , meaning that the advertising value has a positive effect on impulse buying (supported hypothesis). That is, the respondents in this study felt that the advertisements they felt received were useful advertisements which subsequently users felt the urge to buy products or pay for services when the advertisements were displayed. This research is contrast with research conducted by Dodoo \& $\mathrm{Wu}$ (2019) which states that the value of advertising has negatif effect on impulse buying. Hypothesis 3 has a P-value $<.01$ with $\beta$ value of 0.38 , meaning that flow experience has strengthen effect advertising value on impulse buying. Finding in this study is in line with research conducted by Shahpasandi et al. (2020) which states that flow experience has an effect on impulse buying. This summary result is shown in Table 2 .

Table 2. Summary result

\begin{tabular}{lcc}
\hline & P-Value & Result \\
\hline H1 $=$ PA $>$ NI & $<0.01$ & Supported \\
H2 $=$ NI $>$ IB & $<0.02$ & Supported \\
H3 $=$ NI $>$ FE $>$ IB & $<0.01$ & Supported \\
\hline
\end{tabular}

Source: Test result from PLS 7.0 (2021)

\section{CONCLUSION}

This study has theoretical understanding of advertising factor that influence impulse buying. The result confirm that personalized advertising has positive affect to advertising value, then advertising value has positive affect to impulse buying. So, if user feel is easier and see advertising personalization as interesting content, match with their preference the more they feel advertising is useful then can be encouraged to make impulse buying. Then, this study found that the flow experience has strengthen effect advertising value on impulse buying. When user has fully involved and feel happy then excitement when using social media and receive personalize advertising that match with their preference will encourage impulse buying.

In this study, there are several limitations that could be addressed in future study. Firstly, the scope of this research was only limited to examine online impulse buying in one social commerce namely Instagram. However, impulse buying could also be analyzed in other social media or websites. 
Second, this research in Indonesia, the findings may not be generalizable to user in other country. Then, future studies can expand the scope of the research to other countries. Last, in previous research flow experience is key predictor of purchase intention, but the antecedents or predictor and consequences or response of flow experience have not been identified in previous research (Kim \& Han, 2014). So, the further study can examine and identify more key predictor such as skills, interactivity and web design quality.

\section{REFERENCES}

Abdelsalam, S., Salim, N., Alias, R. A., \& Husain, O. (2020). Understanding online impulse buying behavior in social commerce: A systematic literature review. IEEE Access, 8, 89041-89058. https://doi.org/10.1109/ACCESS.2020.2993671

Anggarini, D., \& Permatasari, B. (2020). Impluse buying ditentukan oleh promosi buy 1 get 1 pada pelanggan Kedai Kopi Ketje Bandar. Jurnal Bisnis Darmajaya, 6(2), 27-37. https://jurnal.darmajaya.ac.id/index.php/JurnalBisnis/issue/viewFile/124/22

Baek, T., \& Morimoto, M. (2012). Stay away from me. Journal of Advertising, 41(1), 59-76. https://doi.org/10.2753/JOA0091-3367410105

Bang, H., Choi, D., Wojdynski, B. W., \& Lee, Y. I. (2019). How the level of personalization affects the effectiveness of personalized ad messages: The moderating role of narcissism. International Journal of Advertising, 38(8), 1116-1138. https://doi.org/10.1080/02650487.2019.1590069

Chang, C. C. (2013). Examining users intention to continue using social network games: A flow experience perspective. Telematics and Informatics. 30(4), 311-321. https://dl.acm.org/doi/abs/10.1016/j.tele.2012.10.006

Chen, Q., Feng, Y., Liu, L., \& Tian, X. (2019). Understanding consumers' reactance of online personalized advertising: A new scheme of rational choice from a perspective of negative effects. International Journal of Information Management, 44, 53-64. https://doi.org/10.1016/j.ijinfomgt.2018.09.001

Dawson, S., \& Kim, M. (2010). Cues on apparel web sites that trigger impulse purchases. Journal of fashion marketing and management, 14(2), 230-246. https://doi.org/10.1108/13612021011046084

Dehghani, M., Niaki, M. K., Ramezani, I., \& Sali, R. (2016). Evaluating the influence of YouTube advertising for attraction of young customers. Computers in Human Behavior, 59, 165-172. https://doi.org/10.1016/j.chb.2016.01.037

De Keyzer, F., Dens, N., \& De Pelsmacker, P. (2015). Is this for me? How consumers respond to personalized advertising on social network sites. Journal of Interactive Advertising, 15(2), 124 134. https://doi.org/10.1080/15252019.2015.1082450

Dodoo, N. A., \& Wu, L. (2019). Exploring the anteceding impact of personalised social media advertising on online impulse buying tendency. International Journal of Internet Marketing and Advertising, 13(1), 73-95. https://doi.org/10.1504/IJIMA.2019.097905

Ducoffe, R. H. (1995). How consumers assess the value of advertising. Journal of Current Issues and Research in Advertising, 17(1), 1-18. http://dx.doi.org/10.1080/10641734.1995.10505022

Grandon, E. E., \& Pearson, J. M. (2004). Electronic commerce adoption: An empirical study of small and medium US businesses. Information and Management, 42(1), 197-216. https://doi.org/10.1016/j.im.2003.12.010

Huang, Z., \& Benyoucef, M. (2013). From e-commerce to social commerce: A close look at design features. Electronic Commerce Research and Applications, 12(4), 246-259. https://doi.org/10.1016/j.elerap.2012.12.003

Iyer, G. R., Blut, M., Xiao, S. H., \& Grewal, D. (2020). Impulse buying: A meta-analytic review. Journal of the Academy of Marketing Science, 48, 384-404. https://doi.org/10.1007/s11747-01900670-w

Kim, Y. J., \& Han, J. (2014). Why smartphone advertising attracts customers: A model of web advertising, flow, and personalization. Computers in Human Behavior, 33, 256-269. https://doi.org/10.1016/j.chb.2014.01.015

Lee, E. B., Lee, S. G., \& Yang, C. G. (2017). The influences of advertisement attitude and brand attitude on purchase intention of smartphone advertising. Industrial Management and Data 
Systems, 117(6), 1011-1036. https://doi.org/10.1108/IMDS-06-2016-0229

Liang, T. P., \& Turban, E. (2011). Introduction to the special issue social commerce: A research framework for social commerce. International Journal of Electronic Commerce, 16(2), 5-13. https://doi.org/10.2753/JEC1086-4415160201

Lina, L. F., \& Setiyanto, A. (2021). Privacy concerns in personalized advertising effectiveness on social media. Sriwijaya International Journal of Dynamic Economics, 5(2), 147-156. http://sijdeb.unsri.ac.id/index.php/SIJDEB/article/download/225/177

Liu, C.-L. E., Sinkovics, R. R., Pezderka, N., \& Haghirian, P. (2012). Determinants of consumer perceptions toward mobile advertising: A comparison between Japan and Austria. Journal of Interactive Marketing, 26(1), 21-32. https://www.researchgate.net/publication/229892383_Determinants_of_Consumer_Perceptions_t oward_Mobile_Advertising_-_A_Comparison_between_Japan_and_Austria

Liyanage, O., \& Wijesundara, B. (2020). Online impulse buying behavior: A review on conceptual and practice perspectives. Global Scientific Journal, 8(2), 3749-3765. https://doi.org/10.11216/gsj.2020.02.35479

Novak, T. P., Hoffman, D. L., \& Duhachek, A. (2003). The influence of goal-directed and experiential activities on online flow experiences. Journal of Consumer Psychology, 13(1), 316. https://doi.org/10.1207/153276603768344744

Olsen, S. O., Tudoran, A. A., Honkanen, P., \& Verplanken, B. (2016). Differences and similarities between impulse buying and variety seeking: A personality-based perspective. Psychology \& Marketing, 33(1), 36-47. https://researchportal.bath.ac.uk/en/publications/differences-andsimilarities-between-impulse-buying-and-variety-s

Park, E. J., Kim, E. Y., Funches, V. M., \& Foxx, W. (2012). Apparel product attributes, web browsing, and e-impulse buying on shopping websites. Journal of Business Research, 65(11), 1583-1589. https://ideas.repec.org/a/eee/jbrese/v65y2012i11p1583-1589.html

Rook, D. W., \& Fisher, R. J. (1995). Normative behavior influences on impulsive buying trait aspects of buying impulsiveness. Journal of Consumer Research, 22(3), 305-313. https://doi.org/10.1086/209452

Shahpasandi, F., Zarei, A., \& Nikabadi, M. S. (2020). Consumers' impulse buying behavior on Instagram: Examining the influence of flow experiences and hedonic browsing on impulse buying. Journal of Internet Commerce, 19(4), 437-465. https://doi.org/10.1080/15332861.2020.1816324

Shanahan, T., Tran, T. P., \& Taylor, E. C. (2019). Getting to know you: Social media personalization as a means of enhancing brand loyalty and perceived quality. Journal of Retailing and Consumer Services, 47, 57-65. https://doi.org/10.1016/j.jretconser.2018.10.007

Srinivasan, S. S., Anderson, R., \& Ponnavolu, K. (2002). Customer loyalty in e-commerce: An exploration of its antecedents and consequences. Journal of Retailing, 78(1), 41-50. https://doi.org/10.1016/S0022-4359(01)00065-3

Sun, T., \& Wu, G. (2011). Trait predictors of online impulsive buying tendency: A hierarchical approach. Journal of Marketing Theory and Practice, 19(3), 337-346. https://doi.org/10.2753/MTP1069-6679190307

Thompson, E. R., \& Prendergast, G. P. (2015). The influence of trait affect and the five-factor personality model on impulse buying. Personality and Individual Differences, 76, 216-221. https://www.sciencedirect.com/science/article/abs/pii/S0191886914007533

Ünal, S., Erciş, A., \& Keser, E. (2011). Attitudes towards mobile advertising: A research to determine the differences between the attitudes of youth and adults. Procedia Social and Behavioral Science, 24, 361-377. https://doi.org/10.1016/J.SBSPRO.2011.09.067

Van Doorn, J., \& Hoekstra, J. C. (2013). Customization of online advertising: The role of intrusiveness. Marketing Letters, 24(4), 339-351. https://doi.org/10.1007/s11002-012-9222-1

Van Reijmersdal, E. A., Rozendaal, E., Smink, N., Van Noort, G., \& Buijzen, M. (2017). Processes and effects of targeted online advertising among children. International Journal of Advertising, 36(3), 396-414. https://doi.org/10.1080/02650487.2016.1196904

Verplanken, B., \& Herabadi, A. (2001). Individual differences in impulse buying tendency: Feeling and no thinking. European Journal of Personality, 15(1), 71-83. https://www.researchgate.net/publication/227911258_Individual_Differences_in_Impulse_Buyin 
Jurnal Manajemen Maranatha a Vol. 21 Nomor 1, November (2021)

g_Tendency_Feeling_and_No_Thinking

Xu, D. J., Liao, S. S., \& Li, Q. (2008). Combining empirical experimentation and modeling techniques: A design research approach for personalized mobile advertising applications. $\begin{array}{lllr}\text { Decision Support } & \text { Systems, } & \text { 740-724. }\end{array}$ https://scholars.cityu.edu.hk/en/publications/combining-empirical-experimentation-andmodeling-techniques(0ab63eab-c359-4f4e-8070-42f0bb3669ce).html

Zhang, J., \& Mao, E. (2016). From online motivations to ad clicks and to behavioral intentions: An empirical study of consumer response to social media advertising. Psychology and Marketing, 33(3), 155-164. https://doi.org/10.1002/mar.20862

Zhang, Y., Liu, L., \& Ho, S. Y. (2020). How do interruptions affect user contributions on social commerce?. Information Systems Journal, 30(3), 535-565. https://doi.org/10.1111/isj.12266 